EWA MATCZUK* - LUBLIN

\title{
FUNKCJA EDUKACYJNA BIBLIOTEKI UCZELNIANEJ NA PRZYKLADZIE BIBLIOTEKI POLITECHNIKI LUBELSKIEJ
}

W czasach intensywnego rozwoju technologicznego i dominacji Internetu warsztat pracy biblioteki i jej oferty ciągle się przeobraża. Biblioteka akademicka jako centrum informacji zapewnia dostęp do drukowanych źródeł wiedzy bądź elektronicznych, a także uczy efektywnego wyszukiwania, selekcji, oceny i zastosowania informacji, spełniając funkcję edukacyjną. Jednym ze statutowych zadań biblioteki akademickiej jest prowadzenie działalności naukowo-badawczej, usługowej i dydaktycznej. Rolą biblioteki akademickiej jest wspomaganie rozwoju kompetencji informacyjnych przydatnych na każdym etapie życia. Nie powinien ten proces kończyć się w momencie uzyskania przez studenta dyplomu ukończenia studiów ${ }^{1}$. Użytkownicy pokolenia Google pozyskują informacje bardzo powierzchownie. Dane, które znajdą w wyszukiwarce, są dla nich wystarczające, nie zwracają uwagi na jakość źródeł, a wyszukiwarka Google jest jedynym etapem w procesie wyszukiwania informacji. Dlatego też, biblioteka akademicka musi nauczyć czytelników wykorzystania w pracy naukowej serwisów, zwierających treści odpowiadające poziomowi akademickiemu². Usługi oferowane przez bibliotekę, różnorodność platform naukowych i baz wymuszą na użytkowniku konieczność opanowania strategii poruszania się po tych narzędziach. Niezbędne są szkolenia czy warsztaty pozwalające na opanowanie przynajmniej podstawowych kompetencji informacyjnych. Ze względu na konieczność ustawicznej edukacji w społeczeństwie uczącym się użytkownikami biblioteki akademickiej są nie tylko pracownicy, studenci, ale i emeryci, uczniowie szkół średnich. Największą grupę stanowią studenci potrzebujący podstawowych materiałów do studiowania.

* Ewa Matczuk - mgr bibliotekoznawstwa i informacji naukowej, kustosz dyplomowany, kierownik Oddziału Informatyzacji Biblioteki Politechniki Lubelskiej, e-mail: e.matczuk@pollub.pl

${ }^{1}$ L. Nalewajska, Dydaktyka w bibliotece akademickiej. Analiza potrzeb i możliwych zmian, „Przegląd Biblioteczny”, 1 (2013) s. 20.

${ }^{2}$ L. Mikołajuk, Udziat biblioteki akademickiej w ksztatceniu kompetencji informacyjnych studentów Uniwersytetu Łódzkiego, s. 288, http://delibra.bg.polsl.pl/Content/15574/Mikolajuk_Lidia_ tekst.pdf (dostęp: 10.02.2016). 
Większe wymagania mają pracownicy naukowi, którzy poszukują informacji ze źródeł prezentujących najnowsze osiągnięcia.

Dzięki staraniom dyrekcji biblioteki, wzrost znaczenia roli pedagogicznej bibliotekarzy został dostrzeżony przez władze Politechniki Lubelskiej. Przedmioty, takie jak Przysposobienie biblioteczne i Informacja naukowa, wpisano w 2014 roku w siatkę zajęć obowiązkowych dla wszystkich wydziałów na mocy Uchwały Nr 49/2013/VII Senatu PL z dnia 26.09.2013 roku³. Zajęcia są obowiązkowe dla studiów stacjonarnych i niestacjonarnych pierwszego stopnia - Przysposobienie biblioteczne, oraz dla studiów drugiego stopnia - Informacja naukowa. Oba przedmioty, w wymiarze dwóch godzin każdy, kończą się uzyskaniem zaliczenia bez oceny (bez punktów ECTS). Zajęcia $z$ informacji naukowej prowadzi sześciu bibliotekarzy, w tym czterech kustoszy dyplomowanych, kustosz i starszy bibliotekarz. Przygotowano sylabusy do tych przedmiotów dla każdego kierunku. Ponadto opracowano podręcznik w wersji elektronicznej - Informacja naukowa. Materiały pomocnicze. Poradnik 2015 - zamieszczony w otwartym dostępie w Bibliotece Cyfrowej oraz na stronie Biblioteki ${ }^{4}$. Zajęcia prowadzone są $\mathrm{w}$ formie wykładu, połączone $\mathrm{z}$ warsztatami aktywnego wyszukiwania informacji w omawianych zasobach elektronicznych. Celem zajęć jest zapoznanie słuchaczy ze źródłami informacji naukowej oraz przedstawienie sposobów jej wyszukiwania w zasobach elektronicznych. Ponadto zapoznanie studentów z metodami zarządzania informacją naukową, selekcją, weryfikacją i zastosowaniem w pracy naukowej.

Przysposobienie biblioteczne od dwóch lat prowadzi 15-16 osób. Wśród dość licznej grupy szkoleniowców są bibliotekarze, starsi bibliotekarze czy kustosze $\mathrm{z}$ różnych oddziałów biblioteki. Zajęcia odbywają się w formie wykładu - prezentacji multimedialnej oraz ćwiczeń. Celem szkolenia jest zapoznanie studentów z zasadami korzystania z zasobów Biblioteki Politechniki Lubelskiej - drukowanych i elektronicznych. Podczas zajęć nabywają umiejętność wyszukiwania i zamawiania w katalogu online potrzebnych materiałów. Dowiadują się, gdzie znajdują się czytelnie oraz z jakich zborów można w nich korzystać, a także w jaki sposób rozmieszczony jest księgozbiór w wolnym dostępie. Zajęcia kończą się zaliczeniem i wpisem do indeksu. Bibliotekarze po zajęciach rejestrują zaliczenie zajęć każdemu studentowi w systemie bibliotecznym. Po wpis do indeksu mogą zgłosić się do każdego z bibliotekarzy, w każdej bibliotece specjalistycznej, czytelni lub wypożyczalni

Oprócz wyżej wymienionych zajęć od 2015 roku prowadzone są szkolenia w zakresie przygotowania w postaci książki, rozprawy doktorskiej dla doktorantów Wydziału Elektrotechniki i Informatyki. Zajęcia prowadzi dwóch bibliotekarzy pracujących w Ośrodku ds. Wydawnictw i Biblioteki Cyfrowej. Są to cztery godziny w semestrze. Dodatkowo odbywają się konsultacje indywidualne dla zainteresowanych.

\footnotetext{
${ }^{3}$ Załącznik nr 4 do Uchwały Nr 49/2013/VII Senatu PL z dnia 29.09.2013.

${ }^{4}$ W zakładce Dla studentów znajduje się link do publikacji http://biblioteka.pollub.pl/sites/ default/files/pdf/Informacja\%20Naukowa\%20-\%20Poradnik_online.pdf.
} 
W naszej ofercie przewidziane są też zajęcia i konsultacje indywidualne dla wszystkich użytkowników. Dla pracowników naukowych Ośrodek Informacji Naukowo-Technicznej prowadzi indywidualne konsultacje w zakresie analiz naukometrycznych do oceny pracownika i awansu zawodowego oraz $\mathrm{w}$ zakresie wymagań ustawy o systemie informacji o nauce itp.

Biblioteka akademicka nastawiona jest głównie na obsługę procesu dydaktycznego i badań naukowych prowadzonych na swojej uczelni oraz w środowisku swojego miasta. Jest jednak też jednostką publiczną mającą obowiązek dzielenia się swoją wiedzą, doświadczeniem, zbiorami z całym społeczeństwem. Dlatego też powinna dążyć do tego, aby być postrzegana jako instytucja otwarta, przyjazna. Biblioteki, przeobrażając się w centra informacji i wiedzy, otwierają się coraz bardziej na różne środowiska. Stąd też instytucje te organizują różne formy upowszechniania wiedzy przez warsztaty, pokazy dla różnych grup użytkowników, nie tylko pracowników naukowych i studentów swojej macierzystej uczelni. Są one kierowane również do bibliotekarzy innych bibliotek, uczniów szkół gimnazjalnych i licealnych, a także do osób w wieku dojrzałym. Wychodząc naprzeciw oczekiwaniom społeczeństwa informacyjnego, bibliotekarze pełnią rolę przewodników, konsultantów i instruktorów w zakresie informacji dostępnej przez Internet ${ }^{5}$.

W Bibliotece Politechniki Lubelskiej, we współpracy z Sekcją Bibliotek Naukowych Akademickiego Koła Stowarzyszenia Bibliotekarzy Polskich w Lublinie, organizowane są wykłady, szkolenia, np. o wykorzystaniu Facebooka, internetowych zagrożeniach. Prowadzą je pracownicy lub zaproszeni goście.

Biblioteka Politechniki Lubelskiej od kilku lat bierze aktywnie udział w Lubelskim Festiwalu Nauki, co roku mamy stanowisko podczas pikniku pt. Życie jest księgą. Od dwóch lat przygotowywane są projekty dla różnych grup użytkowników. Dotychczas odbyły się dwa projekty - pokazy dla osób niewidomych i słabowidzących. Pierwszy w 2014 roku - Tyfloinformatyka powiększa możliwości prezentacja stanowiska komputerowego dla osób niewidomych $i$ słabowidzących. W trakcie spotkania zaprezentowano nowoczesne stanowisko komputerowe przystosowane dla osób niewidomych, niedowidzących oraz głuchych, znajdujące się w Bibliotece Politechniki Lubelskiej. Drugi projekt w 2015 roku - Nowoczesne technologie szansa dla osób niepetnosprawnych, przedstawiono najnowsze metody, dzięki którym osoby niewidome i słabowidzące mogą korzystać z komputera, pracować zawodowo, kształcić się oraz podnosić swoje kwalifikacje. Uczestnicy spotkania dowiedzieli się, w jaki sposób, dzięki programom udźwiękawiającym, powiększającym i wykorzystującym Braille'a, osoby niewidome mogą swobodnie korzystać z komputera. Ponadto odbyła się prezentacja wideotelefonu, który jest tłumaczem on-line języka migowego, dzięki któremu osoby niesłyszące mogą uzyskać fachową informację na uczelni, w bibliotece. Oprócz przeglądu nowoczesnych technologii uczestnicy projektu mieli okazję dowiedzieć się, czym jest

5 A. Komperda, Biblioteka uczaca, „Elektroniczny Biuletyn Informacyjny Bibliotekarzy”, 5 (1999) http://www.oss.wroc.pl/biuletyn/ebib05/a_komperda.html (dostęp: 10.02.2016). 
audiodeskrypcja, oraz zobaczyć, jak wygląda książka dotykowa dla niewidomych dzieci. Projektowi towarzyszyła również wystawa książek dla tych dzieci.

W roku 2015 poszerzono ofertę na Festiwalu. Przygotowano warsztaty dla młodzieży gimnazjalnej dotyczące bezpieczeństwa w sieci Internetowa samoobrona oraz dla seniorów Senior na czasie - jak być w statym kontakcie z bliski$m i$ ? Projekt skierowany do gimnazjalistów miał na celu zapoznanie słuchaczy z zagrożeniami w sieci oraz sposobami ich unikania. Na przykładzie prawdziwych incydentów, prowadzący przedstawił mechanizmy występowania niektórych zagrożeń. Warsztaty przeznaczone dla osób starszych przybliżyły nowoczesne media społecznościowe, jako doskonały sposób radzenie sobie z samotnością, wyobcowaniem, a także narzędzie umożliwiające kontakt $\mathrm{z}$ bliskimi. Podczas zajęć seniorzy mieli okazję nauczyć się wykorzystywania takich narzędzi, jak: Facebook, Skype czy Gadu-Gadu. Na warsztatach przedstawiono, w jaki sposób można zarejestrować się do Facebooka, oraz pokazano i przećwiczono podstawowe funkcjonalności danych komunikatorów: umieszczanie postów, poszukiwania znajomych, umieszczanie zdjęć oraz używanie czatu. Ponadto zaprezentowano instalację i konfigurację najpopularniejszych komunikatorów - Skype i Gadu-Ga$\mathrm{du}$ - umożliwiających prowadzenie rozmów telefonicznych i wideorozmów oraz przesyłanie plików. Dodatkowo spotkania te były okazją do poznania nowych ludzi.

Aby sprostać wymaganiom użytkowników, społeczeństwa informacyjnego sami bibliotekarze muszą być doskonale wyszkoleni. Są zobligowani do ustawicznego podwyższania swoich kwalifikacji zawodowych. W tym celu od kilku lat są organizowane cykliczne spotkania w piątki, podczas których bibliotekarze prezentują wybraną bazę. Dzięki temu sami zagłębiają wiedzę o wybranym źródle, ucząc również innych. W Bibliotece Politechniki Lubelskiej w roku 2014 r. przygotowano i udostępniono na platformie e-learningowej kursy, które miały na celu podniesienie kwalifikacji bibliotekarzy dziedzinowych. Składały się z sześciu modułów. Pierwszy z nich dotyczył definicji używanych w naszej codziennej pracy bibliotekarskiej. Drugi - baz danych, katalogów, serwisów. Trzeci obejmował wiedzę o parametryzacji. W czwartym bibliotekarze mogli wykazać się swoją znajomością dziedzin wiedzy i ze znajomości strony www biblioteki. Piąty - codziennego narzędzia - nowego interfejsu katalogu - Chamo. Każdy moduł kończył się testem.

Obecnie w Bibliotece Politechniki Lubelskiej przygotowuje się opracowanie strategii szkoleń użytkowników oraz podnoszenia kwalifikacji pracowników, która zakłada realizację działań wspomagających budowanie społeczeństwa wiedzy opartej na zasobach cyfrowych i tradycyjnych, w nowoczesnej komunikacji naukowej. Określono grupy docelowe szkoleń oraz programy dla grup: studenci I roku, studenci IV roku, studenci i doktoranci obcojęzyczni, pracownicy naukowi oraz pracownicy biblioteki.

Oblicze biblioteki naukowej się zmienia. Biblioteka to nie tylko „trzecie miejsce", ale przede wszystkim centrum edukacji. Jako centrum informacji i wie- 
dzy, integrując różne formy usług informacyjnych, jest też miejscem spotkań ${ }^{6}$. W związku z tym zmieniły się też zadania bibliotekarza w kierunku edukacyjnym, czyli kształtowania kompetencji informatycznych. Nie tak dawno jeszcze bibliotekarz był niezbędny w komunikacji czytelników z biblioteką, obecnie wyręczać zaczynają go elektroniczne media. Dlatego też trzeba w tej sytuacji umieć wykorzystać te narzędzia (Facebook, Skype itp.) jako sprzymierzeńców do nauki. Nowe technologie pomagają bibliotekarzowi.

Biblioteka obecnie zaczyna być formą pośrednictwa między kompetencją informacyjną a umiejętnością korzystania z mediów?

Dlatego też ważne jest to, aby właściwie przygotować użytkowników do posługiwania się informacją. Przed bibliotekarzem ciągle stoi wyzwanie tworzenia nowych narzędzi dostępu do informacji oraz opanowanie coraz nowszych.

Bibliotekarz musi znać biegle zagadnienia związane z edukacją informacyjną, powinien posiadać predyspozycje do nauczania (odpowiednią wiedzę pedagogiczną) oraz świadomość różnic edukacyjnych studentów. Aby przygotować dobry program szkoleniowy, należy wykazać się co najmniej podstawową praktyczną znajomością dydaktyki. Przygotowanie się do zajęć wymaga od bibliotekarzy dużego nakładu pracy. Ze strony pracowników biblioteki należałoby jeszcze przeszkolić zespół w zakresie umiejętności prowadzenia zajęć ze studentami.

Przed bibliotekarzami stoi również wyzwanie wypracowania dróg współpracy między nimi a pracownikami naukowo-dydaktycznymi w zakresie wspomagania procesu edukacyjnego. Wtedy zajęcia $\mathrm{z}$ informacji naukowej odpowiadałyby rzeczywistym potrzebom studentów, co mogłoby mieć ogromny wpływ na ich zaangażowanie podczas ćwiczeń.

Dwie godziny to niestety za mało, aby w ciągu jednego spotkania przekazać całą wiedzę z zakresu kompetencji i umiejętności informacyjnych. Czasem też szkolenia odbywają się w zbyt licznych grupach. Aby zagwarantować wysoką jakość i skuteczność zajęć, należałoby szukać innych rozwiązań. Wyjściem $\mathrm{z}$ tej sytuacji jest na pewno zwiększenie liczby godzin, zmiana formuły szkolenia (np. częściowy e-learning), metod i środków dydaktycznych. A przede wszystkim ścisła współpraca z pracownikami naukowymi, będąca istotnym elementem skutecznego nauczania i wykorzystywania przez studentów umiejętności informacyjnych.

Słowa kluczowe: Politechnika Lubelska, biblioteka, szkolenia, informacja naukowa, Lubelski Festiwal Nauki

${ }^{6}$ W. Babik, Biblioteka akademicka na rozdrożu: o wspótczesnych przemianach $w$ środowisku informacyjnym bibliotek, http://delibra.bg.polsl.pl/Content/23338/BCPS_25014_-_Biblioteka-akademick_0000.pdf (dostęp: 15.02.2016).

${ }^{7}$ E. Lepkowska, Jaki jest i gdzie jest współczesny czytelnik, s. 9, http://eprints.rclis.org/19569/1/ Emilia\%20Lep-kowska\%20czytelnik.pdf (dostęp: 15.02.2016). 


\title{
BIBLIOGRAFIA
}

\section{Źródla}

Załącznik nr 4 do Uchwały Nr 49/2013/VII Senatu PL z dnia 29.09.2013.

\section{Opracowania}

Babik Wiesław, Biblioteka akademicka na rozdrożu: o współczesnych przemianach $w$ środowisku informacyjnym bibliotek, http://delibra.bg.polsl.p1/Content/23338/BCPS_25014_-_Biblioteka-akademick_0000.pdf(dostęp:15.02.2016).

Komperda Anna, Biblioteka ucząca, „Elektroniczny Biuletyn Informacyjny Bibliotekarzy”, 5 (1999), http://www.oss.wroc.pl/biuletyn/ebib05/a_komperda.html (dostęp:10.02.2016).

Lepkowska Emilia, Jaki jest $i$ gdzie jest współczesny czytelnik, s. 9, http://eprints.rclis. org/19569/1/Emilia\%20Lep-kowska\%20czytelnik.pdf (dostęp: 15.02.2016).

Mikołajuk Lidia, Udział biblioteki akademickiej $w$ kształceniu kompetencji informacyjnych studentów Uniwersytetu Łódzkiego, s. 288, http://delibra.bg.polsl.pl/Content/15574/Mikolajuk Lidia tekst.pdf (dostęp: 10.02.2016).

Nalewajska Lilianna, Dydaktyka w bibliotece akademickiej. Analiza potrzeb i możliwych zmian, „Przegląd Biblioteczny”, 1 (2013) s. 20.

\section{THE EDUCATIONAL FUNCTION OF THE UNIVERSITY LIBRARY \\ ILLUSTRATED WITH THE EXAMPLE OF LUBLIN UNIVERSITY OF TECHNOLOGY LIBRARY}

\begin{abstract}
Summary
The article presents the training offer of Lublin University of Technology Library in the field of information literacy education. It also identifies the role of academic libraries in supporting information literacy at every stage of life through the discussion of services targeted at different users.
\end{abstract}

Keywords: Lublin University of Technology, library, training, research information, Science Festival in Lublin 